\title{
ASSESSING THE RETENTION CAPACITY OF A FLOODPLAIN USING A 2D NUMERICAL MODEL
}

\author{
JANA VALENTOVÁ, PETR VALENTA, LENKA WEYSKRABOVÁ
}

Czech Technical University in Prague, Faculty of Civil Engineering, Thákurova 7, 16629 Praha 6, Czech Republic; Mailto:valenta@fsv.cvut.cz

This paper presents a method for assessing the retention capacity of a floodplain in the course of flooding and for estimating the significance of its water storage for transforming a flood wave. The method is based on two-dimensional numerical modeling of the flood flow in a river channel and in the adjacent floodplains, and is suitable for cases when the morphology of the flooding area is variable and complex, e.g. broad inundation areas with meandering channels. The approach adopted here enables us to quantify the retention capacity for inundation areas of various characters and with various land uses, and provides a tool for estimating the efficiency of possible measures for increasing the water storage capacity of a floodplain. The retention capacity is estimated using an evaluation of a series of detailed flood flow modeling results; the flood wave transformation effect is predicted with the aim of creating a non-linear reservoir model. A parametric study of the floodplain retention capacity for the upper branch of the Lužnice River is presented here, and the results for the current state and for various hypothetical scenarios of changes in geometry and land use are evaluated and compared.

KEY WORDS: Two-dimensional Numerical Modeling, Floodplain Retention Capacity, Transformation of a Flood Wave.

Jana Valentová, Petr Valenta, Lenka Weyskrabová: KVANTIFIKACE RETENČNÍ SCHOPNOSTI NIVY POMOCÍ 2D NUMERICKÉHO MODELU. J. Hydrol. Hydromech., 58, 2010, 4; 20 lit., 7 obr., 2 tab.

V př́spěvku je prezentována metodika pro stanovení retenční kapacity inundačního území při povodňových průtocích a jeho význam pro transformaci povodňové vlny. Metoda využívá dvourozměrný numerický model proudění vody korytem a přilehlým inundačním územím a je vhodná pro případy, kdy charakter nivy je proměnlivý a velmi komplikovaný, např. široká inundační území s meandrujícími toky. Navržený způsob řešení umožňuje kvantifikovat retenční schopnosti niv různého charakteru při různých způsobech využívání a umožňuje případně navrhnout úpravu inundačního území tak, aby transformační účinek při průchodu povodňové vlny byl co největší. Retenční kapacita inundačního území je stanovena na základě výsledků podrobného modelování proudění vody při různých průtokových stavech a transformace povodňové vlny je řešena pomocí iteračního postupu založeného na Bratránkově metodě. V př́spěvku je uvedena parametrická studie kvantifikace retenční kapacity nivy na základě vyhodnocení a porovnání transformační schopnosti pro nivu Lužnice v jejím horním úseku pro současný přrirozený stav a pro různé teoretické scénáře změněného charakteru a způsobu využívání nivy.

KLÍČOVÁ SLOVA: Dvourozměrné numerické modelování, retenční kapacita nivy, transformace povodňové vlny.

\section{Introduction}

Due to the frequent occurrence of flood situations in recent years, a lot of attention is now dedicated to flood protection issues, especially to proposals for measures that might reduce the adverse impacts of floods. In addition to technical measures, such as the construction of reservoirs and dry polders and the implementation of flood control measures in urban areas, it is also possible to implement measures in the landscape that will restore or increase the retention capacity of floodplains. The goal of these measures is to increase the accumulation of water in the area, to reduce the peak flow and delay the peak time of the flood wave. The rate of transformation depends on the shape, the character and the land use of the floodplain area - on its retention capacity. 
Many authors have pointed to the significance of flood water inundating the floodplain for natural transformation of the flood wave (Vopálka and Pařizek, 2000; Květ et al., 2002; Pithart et al., 2003, and others). Qualitative estimates of this effect based on an analogy with the estimated volume of water running in the floodplain during a flood with the retention capacity achievable by constructing water reservoirs and dry polders are, however, only indicative. A quantitative evaluation, including an assessment of the measures implemented in the floodplain area for restoring or increasing the natural retention of floodplain area, has to be based on hydrological and hydraulic models (Kreis, 2003).

In order to evaluate the magnitude of floodplain retention effects and to assess the effects of various types of measures in a floodplain area (revitalization, changes in geometry, changes in land use) leading to an increase in retention capacity, it is necessary to quantify the retention capacity using flood wave transformation analysis in a given river branch.

\section{Ways of assessing the floodplain retention effect}

Solutions to the problem mentioned above can generally be founded on two basic principles - the use of hydrological flood routing models, or the application of hydrodynamic models. Hydrological flood routing models are based on the continuity equation and on a simplified parametric formulation of the flow dynamics in the analyzed stream or river branches (linear or nonlinear reservoir methods, the multilinear Kalinin-Miljukov method, the Muskingum and Muskingum-Cunge methods, and others). Examples of applications are given in Pekár et al., 2001 and in Szolgay et al., 2008). Using an appropriate method, and provided that historical hydrographs are available for model verification, these models can be used not only for a quick analysis of various flood scenarios for the current state, but also to assess the impacts of various measures (construction of retention reservoirs and polders, stream revitalization) on transforming the flood wave (Szolgay et al., 2006). The hydrological approach to a more detailed evaluation of various types of revitalization adjustments is however limited by the schematisation of the flow dynamics that is adopted, and by the fact that lower model resolution provides a less detailed geometric description of the stream channel and the floodplain (Bayerisches Landesamt für Wasserwirtschaft, 2005).
Hydrodynamic models appropriate for studying the water flow in floodplain areas can be categorized according to spatial schematisation, the formulation of the governing equations or according to the numerical method that is applied. An overview of existing methods is given in Valenta (2004). One-dimensional (1D) hydrodynamic models based on the solution of the Saint-Venant equations and using discretization of the real geometry with a set of cross-sections are the most widely used models for solving the passage of the flood flow through the inundation area of interest. This type of model was applied e.g. by Swiatek et al. (2003) and by Zezulák (2006) for determining the retention potential of a floodplain. A recent development of 1D models focuses on complicated cases of highly unsteady problems with singularities and changes in flow regimes, such as the solution of dam break waves and hydraulic shocks (Link and Donoso, 2008 and others).

In the case of complicated flow situations in a floodplain, the theoretical conditions and limitations for the application of a 1D model may not always be met. In addition, the representation of some types of particular revitalization measures and land use changes may not be sufficiently accurate in a 1D model. In these cases, it is appropriate to apply a two-dimensional model (2D) for a detailed analysis of the flood flow conditions. A solution of the transformation of a flood wave in real complex floodplain geometry using an unsteady 2D model is given by Bates et al. (1996), and an application of a 2D model for determining wave retention in a meandering stream is shown by Watanabe and $\mathrm{Fu}$ kuoka (2002). On the basis of 2D model simulations, the study by the Bayerisches Landesamt für Wasserwirtschaft (2005) offers a parametric study of various theoretical adjustments in an imaginary floodplain area (slope changes using bottom drops, meander restoration, changes in land use taking into account full and partial afforestation, and various combinations). The study also includes an example of a practical application of the model for a real inundation area with a complex geometry.

Simulating the routing of a flood wave by an unsteady two-dimensional model poses special demands on computing time, often leading to the need for compromises in model resolution and detail. In complicated models with real geometries, there are numerical difficulties as a consequence of alternate drying and wetting of the terrain edges. In the methodology presented here, we have therefore used a simplified approach, consisting of separate 
simulation of flood flow in the floodplain with a detailed 2D model for substitutive series of quasisteady states. This was followed by an evaluation of the relations between the discharges and the spatial characteristics of the flooded inundation area (water depths, flooded areas and retention volumes) and by subsequent simple analysis of the flood wave transformation using a nonlinear reservoir method. The underlying assumption is that the method can be applied only for relatively short river sections. The approach used here is a 2D analogy to the method of Sartor (2005), which uses a quasistationary 1D model for determining the dischargeretention volume relation.

\section{Solution methodology using a 2D model}

\section{Determining the water flow characteristics}

The method presented here is based on detailed modeling of the water flow in a channel and the adjacent floodplain using the FAST2D twodimensional numerical model. Our version of the model (Valenta, 2004) starts conceptually from the original methodology developed by Wenka and Valenta (1991), and enables very detailed numerical modeling of flood situations in complicated real geometrical conditions of open channels with floodplains, including urbanized areas (Valenta and Valentová, 2003).

The model is based on a set of depth-averaged Reynolds equations consisting of the continuity equation and two momentum equations for the horizontal velocity components. It can be written in the following form (1) :

$$
\begin{aligned}
& \frac{\partial h}{\partial t}+\frac{\partial\left(h u_{i}\right)}{\partial x_{i}}=0 \\
& \frac{\partial\left(h u_{i}\right)}{\partial t}+\frac{\partial}{\partial x_{j}}\left(h u_{i} u_{j}\right)=-\mathrm{g} h \frac{\partial}{\partial x_{i}}\left(h+z_{b}\right)+ \\
& +\frac{1}{\rho} \frac{\partial}{\partial x_{j}}\left(h T_{i j}\right)+h S_{i} ; i, j=1,2 .
\end{aligned}
$$

The equations contain the horizontal axes of the Cartesian coordinate system, $t$ is the time [s], $h-$ the water depth $[\mathrm{m}], z_{b}$ denotes the vertical coordinate of the bottom level [m], $\rho$ - the water density $\left[\mathrm{kg} \mathrm{m}^{-3}\right]$, and $\mathrm{g}$ is the acceleration due to gravity $\left[\mathrm{m} \mathrm{s}^{-2}\right]$. The velocities $u_{1}$ and $u_{2}\left[\mathrm{~m} \mathrm{~s}^{-1}\right]$ are the depth-averaged velocities in the $x_{1}$ and $x_{2}$ directions. The source term $S_{i}\left[\mathrm{~m} \mathrm{~s}^{-2}\right]$ in the momentum equa- tions includes the influence of external forces and stresses, such as the bed shear stress, the stress due to wind on the water level, and the Coriolis acceleration.

The depth-averaged components of the effective stress tensor $T_{i, j}$ are defined as the sum of the laminar stresses, the turbulent stresses and the stresses resulting from the non-uniform velocity distribution in the vertical direction. The effective stresses $T_{i, j}$ are modeled by the eddy viscosity approach in the FAST2D model. The eddy viscosity is calculated with the aid of a depth average version of the k- $\varepsilon$ turbulence model (Rodi, 1980).

The partial differential equations are solved numerically with a control volume procedure. The method employs non-orthogonal curvilinear grids, a non-staggered variable arrangement.

The numerical flow simulation results consist of the components of depth-averaged velocities, water levels and turbulence parameters defined in the centre of each control volume.

The input data necessary for assembling the model of the flood flow in the channel and in the adjacent floodplain includes hydrological, topographic and land surveying data, land use data and data for model calibration, if available.

During practical application of the model, the particular domain of interest has to be covered with the computational grid representing the channel and the floodplain. The grid has to be sufficiently dense to allow detailed modeling of all flow obstacles, e.g. various road embankments, levees or protective dikes, as well as structures in urban areas.

In the next step in the model building procedure, it is necessary to specify the terrain elevation for all grid points using digital terrain model data obtained by land surveying, aerial photogrammetry or laser scanning. The roughness values are an important model input that have a significant effect on the flow characteristics. These values depend on land use, and can be specified with the aid of aerial photographs of the modeled area. To calculate the water flow characteristic in the modeled area for each simulated state, it is necessary to define the corresponding boundary conditions. This involves specifying the discharge distribution along the inlet boundary and in most cases the water level at the outflow boundary. 


\section{Evaluating the floodplain retention capacity and transforming the flood wave}

For the purposes of this study, the floodplain retention capacity is understood as the volume of water that can be held in a flooded area. To quantify the floodplain retention capacity during the course of the flood wave, a quasi-steady approach was applied. Particular 2D water flow simulations were performed for a set of selected discharge values providing a stepwise approximation of the simulated flood hydrograph. The water flow characteristics were acquired from the simulation results, and the flooded areas and flooded volumes were evaluated on the basis of the spatial distribution of the calculated water depths for all simulated flow rates. This data was used for assembling the functional dependency of the flooded area $A\left[\mathrm{~m}^{2}\right]$ and the flooded volume $V\left[\mathrm{~m}^{3}\right]$ on the flow rate $Q$ $\left[\mathrm{m}^{3} \mathrm{~s}^{-1}\right]$.

Due to numerical problems arising from the application of a 2D unsteady model in the complicated geometry of real inundation areas (especially wetting and drying of the model elements), we sought a simpler alternative method for quantifying the retention effects associated with the evaluated retention capacity which would allow an approximate but rapid assessment of the flood wave transformation based on the results of 2D modeling. The flood wave transformation was solved using a nonlinear reservoir method (Bratránek's variant), which can be used for flood wave transformation in a reservoir and also in a river floodplain ( Kemel, 2000). The method is based on the nonlinear balance equation:

$$
\begin{aligned}
& \left(\frac{Q_{p 1}+Q_{p 2}}{2}\right) \Delta t-\left(\frac{Q_{o 1}+Q_{o 2}}{2}\right) \Delta t=V_{2}-V_{1} \\
& V=f(Q)
\end{aligned}
$$

The solution proceeds as a successive numerical integration in time with time step $\Delta t[\mathrm{~s}]$. The nonlinear relationship between the unknown value of outflow $Q_{02}\left[\mathrm{~m}^{3} \mathrm{~s}^{-1}\right]$ at the end of the time interval and the known values $Q_{p 1}, Q_{p 2}$ of the inflow at the beginning and at the end of the interval, the known value of the outflow at the beginning of the previous time step $Q_{\mathrm{o} 1}$ and the nonlinear dependency $V=\mathrm{f}(Q)$ is solved by successive approximation in each integration step. Unlike the solution of the flood wave transformation in a reservoir (assuming a horizontal water level) the relation $V=\mathrm{f}(Q)$ results from the variable spatial distributions of the water elevation in the analyzed branch of the floodplain that were calculated in the previous step with the detailed two-dimensional model. The result is a hydrograph of the transformed flood wave at the outflow boundary of the model.

The usability of the method presented here and the limiting conditions were tested in the following case study by comparing the results with the flood wave transformation obtained with the unsteady 1D hydrodynamic model.

\section{Case study - influence of the character of a floodplain and the land use in the floodplain on the flood wave transformation}

\section{Area of interest-model preparation}

This method for determining the retention potential of a floodplain was applied practically to the upper section of the Lužnice River, between the villages of Nová Ves nad Lužnicí and Halámky. The area of interest is a part of the Třeboňsko nature reserve. In this section, the Lužnice River has a small bottom slope, and the river bed meanders freely across a wide floodplain bordered by river terrace slopes, and there are abundant terrain depressions, blind stream branches and pools of varying depth. The floodplain has a natural character with minimum agricultural adjustments. The floodplain sites were previously managed as meadows and pastures, and they are currently left to natural evolution. The river banks are densely willowed and the floodplain margins are locally wooded.

The modeled area is about $6 \mathrm{~km} \times 1.7 \mathrm{~km}$, while the length of the meandering stream exceeds $10 \mathrm{~km}$. The upper model boundary is located in the bridge profile, enabling appropriate assignment of flow boundary conditions. The lower model boundary condition (water level) was specified by the discharge curve for the expected water level slope consistent with the bottom slope. Due to the complicated geometry, the computational grid was designed very densely, with an average cell size of 2.5 x $2.5 \mathrm{~m}$. A digital terrain model was created using data obtained from aerial photogrammetry in combination with land surveys of the river cross sections. A visualization of the terrain model implemented in the numerical model is shown in Fig. 1. In the area of interest, ten different types of land use with different roughness coefficients were identified on the basis of aerial photography, a field survey and other data. They characterize the stream channel, cutoffs, pools, meadows and fields, woods, 


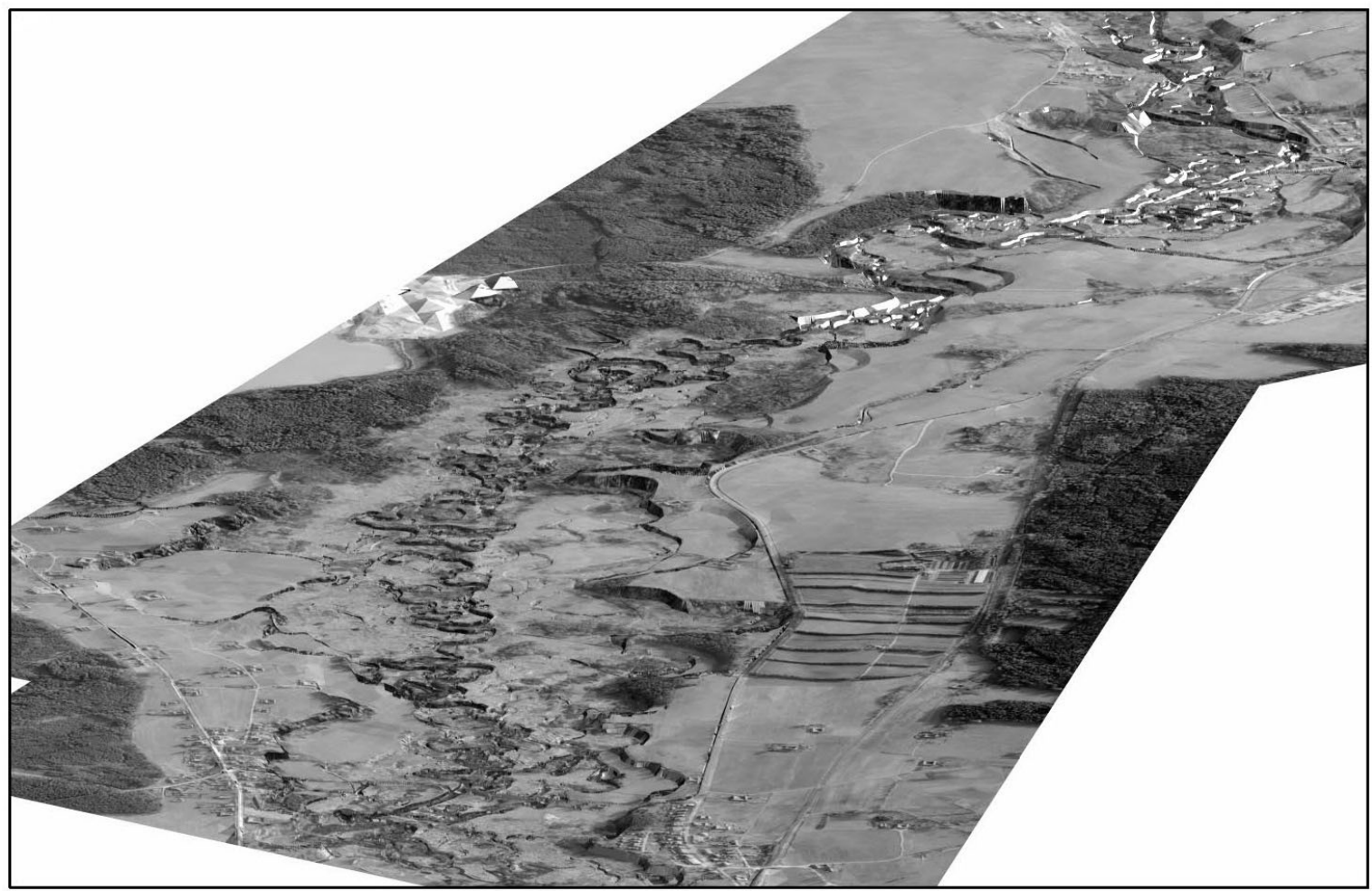

Fig. 1. Visualization of a terrain model for the current state - Scenario A. Obr. 1. Vizualizace modelu terénu pro skutečný stav nivy - scénáŕ A.

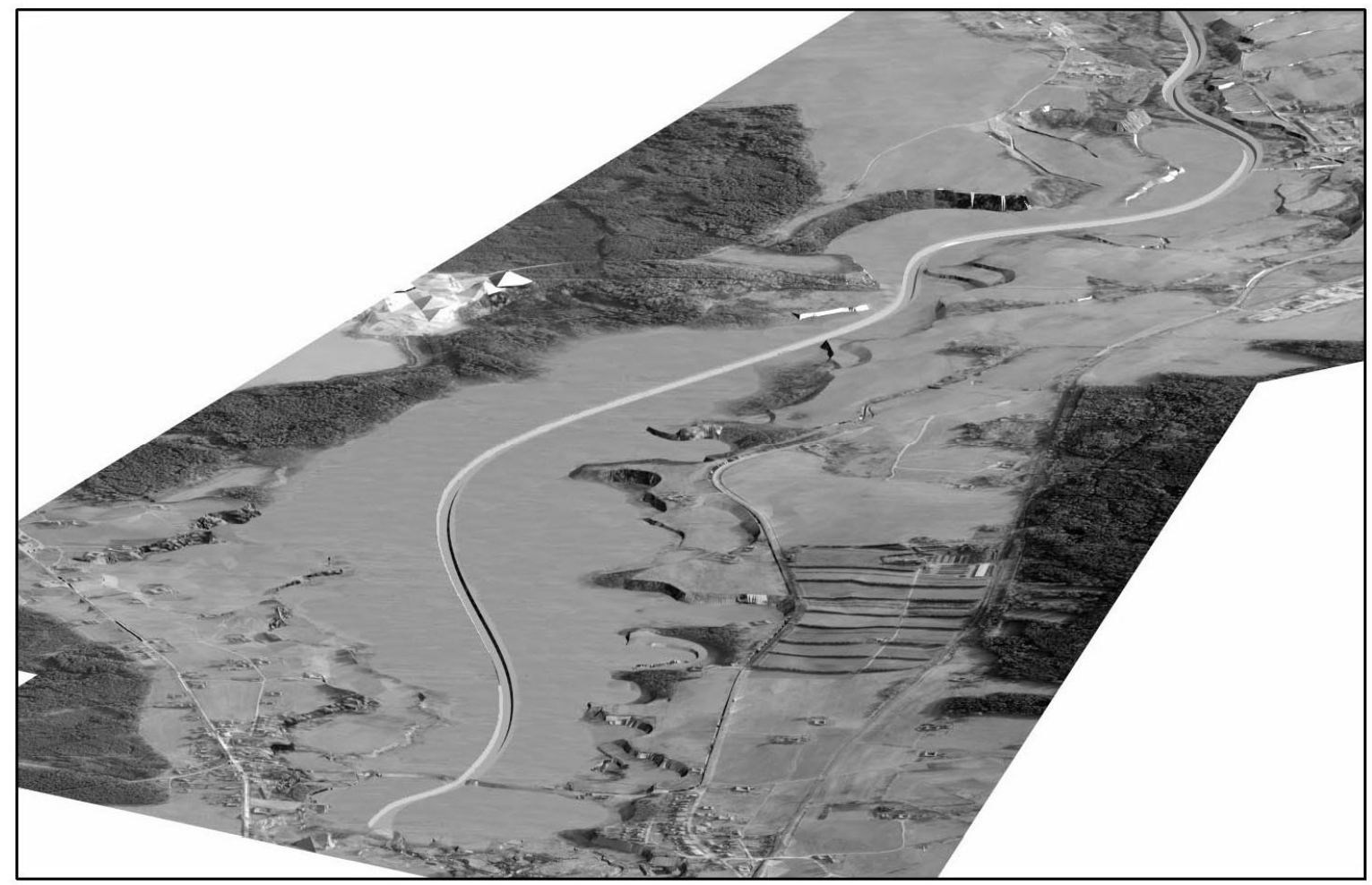

Fig. 2. Visualization of a terrain model for the modified state - Scenario D. Obr. 2. Vizualizace modelu terénu pro upravený stav - scénář D. 
urban areas, etc. Unfortunately, no calibration data was available in the area of interest, and the values of the roughness coefficients had to be estimated by analogy with the calibration results for other similar localities.

\section{Evaluating the retention capacity and verifying the flood wave transformation}

A numerical model of the flood flow in the selected branch of the Lužnice was used to verify the practical applicability of the methodology for determining the retention capacity of a floodplain and its impact on flood wave transformation. The 2D flow simulations and the evaluation of the flow characteristics were performed for a selected set of quasi-steady flow states, and the simulation results were used as a basis for evaluating the floodplain retention capacity expressed as the dependency of the flooded areas and volumes on the discharge (see Fig. 5, Scenario A). Subsequently, the transformations of theoretical flood waves with peak discharges $Q_{100}, Q_{20}$ and $Q_{5}$ (peak discharges with 100 , 20 and 5 year return periods) were calculated using the procedure described above. Theoretical flood wave hydrographs were obtained from the Czech Hydrometeorological Institute.

The transformation of the flood hydrograph was calculated in two variants. In the first variant, the entire floodplain was considered as one total balance unit (by analogy with one reservoir). The second variant was considered as a multi-sectional model composed of five successive sections (similar to a cascade of reservoirs). The simulation time step was 30 minutes for each variant.

In the area of interest (a nature reservation), no time records of real flood waves are available for the calibrating of the model. A comparison of the results with the simulations obtained with a reference hydrodynamic model was used to verify the flood wave transformation method that was applied. The HEC RAS unsteady 1D model (USACE, 2001), based on the solution of the Saint-Venant equations, was applied for this purpose. Cross sections for a 1D model were created as cuts across the digital terrain model, identical with the terrain model for 2D modeling. The model consisted of 160 cross sections at average distances of $160 \mathrm{~m}$. For the simulations, the model was loaded with flow hydrographs consistent with cases simulated with the quasistationary approach. All unsteady simulations were performed with a two-minute time step.
A comparison of the results for theoretical flood waves with peak discharges $Q_{100}, Q_{20}$ and $Q_{5}$ obtained with these two approaches is documented in Fig. 3. The curves marked A correspond to the input hydrographs. Other curves represent the transformed waves at the outflow boundary of the model. Curves B were obtained using the reference $1 \mathrm{D}$ hydrodynamic model, and curves $\mathrm{C}$ and $\mathrm{D}$ are the results of the solution approach described above. Curves $\mathrm{C}$ were obtained by using the onesectional model, while curves $\mathrm{D}$ resulted from the multi-sectional model.

On the basis of the qualitative comparison, it can be stated that the wave hydrograph shapes obtained by the different methods agree quite well, especially in terms of the time lag of the transformed wave. For the $\mathrm{C}$ curves (one-sectional model), there are noticeable differences in the absolute peak discharge values, while the results of the multisectional model are practically identical with the referential results of the 1D hydrodynamic model.

An important factor affecting the choice of an appropriate method for calculating the flood wave transformation is the steepness of the hydrograph. Fig. 4 documents an example of a hypothetical wave which was obtained on a basis of a hydrograph with peak discharge $Q_{100}$ by threefold reduction of the duration of the flood wave. For such a steep wave, the results of the one-sectional model (curve C) are no longer satisfactory. The solution is to apply a multi-sectional model (curve D) or some other more appropriate approach to wave transformation.

\section{Choosing scenarios and simulations}

The aim of this study was to access the influence of various theoretical variants of changes in geometry and in land use on the retention capacity of a floodplain. The simulations of the flood flow and the evaluation of the flow characteristics were realised for the current state in the domain of interest and also for a total of six different scenarios of terrain modifications and changes in land use. A summary of the scenarios is shown in Tab. 1 .

The current natural state of the floodplain is described by Scenario A. In comparison with the current state, Scenario B assumes a considerable increase in roughness in the floodplain due to total afforestation. By contrast, Scenario C describes the situation if the whole floodplain area were to be cultivated as arable land and if the surface were 


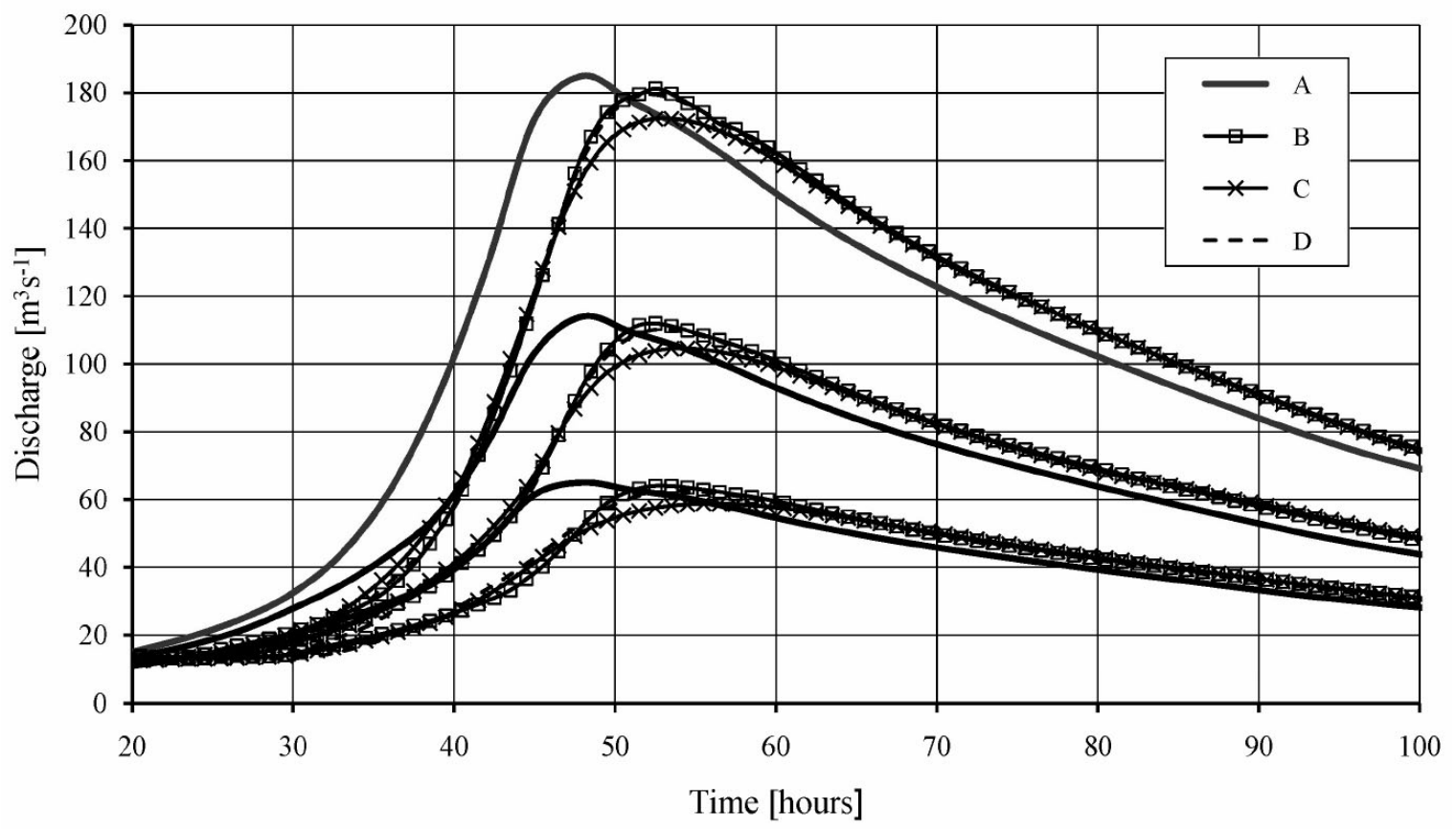

Fig. 3. Comparison of flood wave transformation results for various peak discharges; (A - inflow flood wave, B - 1D hydrodynamic model, $\mathrm{C}$ - one-sectional model, $\mathrm{D}$ - multi-sectional model).

Obr. 3. Porovnání výpočtu transformace povodňových vln s různým kulminačním průtokem; (A - vstupní vlna, B - hydrodynamický 1D model, C - jednosekční model, D - vícesekční model).

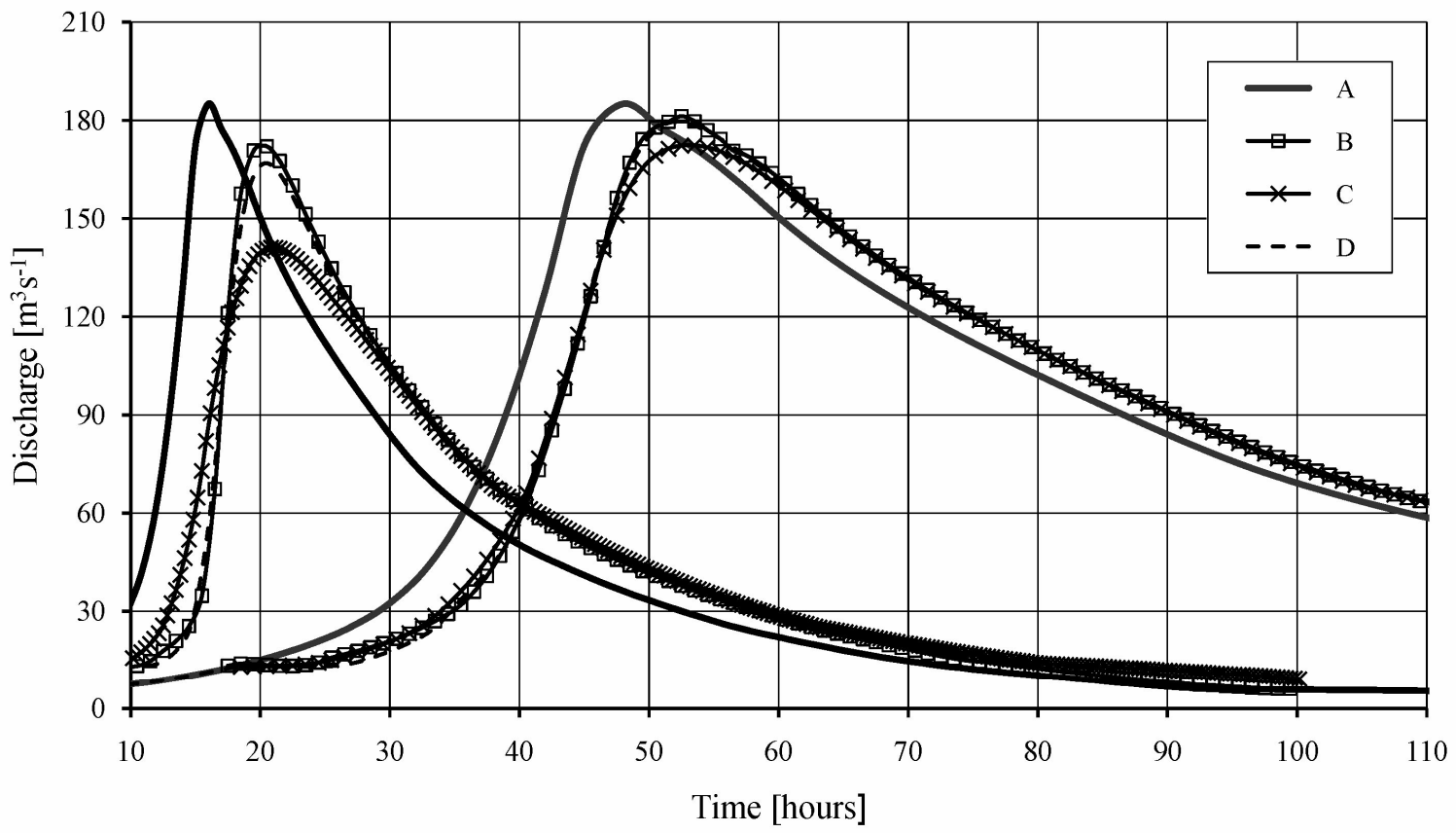

Fig. 4. Comparison of flood wave transformation results for a steep flood wave and for a flat flood wave; (A - inflow flood wave, B - 1D hydrodynamic model, C - one-sectional model, D - multi-sectional model).

Obr. 4. Porovnání výpočtu transformace vlny pro strmou a plochou povodňovou vlnu; (A - vstupní vlna, B - hydrodynamický 1D model, C - jednosekční model, D - vícesekční model). 
$\mathrm{T} \mathrm{a}$ b le 1. Summary of scenarios.

T a b u $1 \mathrm{k}$ a 1 . Souhrn zkoumaných scénářù.

\begin{tabular}{ccccc}
\hline \multirow{2}{*}{ Scenario } & \multirow{2}{*}{ Floodplain } & \multirow{2}{*}{ Channel } & Land use & Roughness \\
\cline { 5 - 5 } & & & & channel/floodplain \\
\hline A & original & modified & original & $0.08 / 0.08-0.14$ \\
B & original & original & forestation & $0.08 / 0.14$ \\
C & original & original & deforestation & $0.08 / 0.05$ \\
D & modified & modified & arable land & $0.02 / 0.05$ \\
E & modified & modified & forestation & $0.02 / 0.14$ \\
F & modified & original & active zone & $0.08 / 0.08-0.14$ \\
G & dikes & modified & arable land & $0.02 / 0.05$ \\
\hline
\end{tabular}

smoother than it is at present. The modifications in Scenarios D, E and G assume changes in geometry, including improvements to the river channel and changes in the shape of the terrain in the floodplain. Channel improvement is characterized by changing the river line together with a corresponding reduction in channel length and increase in the longitudinal bottom slope. The natural cross section is improved to a trapezoidal channel shape with protection of the bottom and the slopes with low roughness, having flow capacity values of about $Q_{5}-Q_{10}$ Field engineering is assumed in the floodplain; the floodplain surface is adjusted and aligned to the edge of the river terrace. In variant $\mathrm{D}$, land use as arable land with no bank vegetation is assumed, while variant $E$ considers surface roughening due to floodplain afforestation. Scenario $G$ originated from Scenario D, with the adjusted floodplain supplemented by three cross dikes on both sides of the river with a view to increasing the water storage and thus improving the retention capacity of the floodplain. Finally, Scenario F is based on the current state and assumes parallel floodplain area diking at the so-called "active zone" boundaries - with this, a part of the floodplain behind the dikes is removed from the flood flow passage. The "active zone" assessment methodology used in the Czech Republic considers the active zone to be the river channel and the adjacent parts of the floodplain transferring at least $80 \%$ of peak discharge $Q_{100}$ with a 100 -year return period. The specification of this zone was based on analyses of the 2D simulation results (flood flow pattern, streamlines).

Necessary simulations were performed and flood flow characteristics including water elevations, water depths and flow velocities with streamlines were evaluated for particular variants.

A comparison of the flow characteristic evaluations confirms a significant influence of floodplain roughness on the velocity and water depth values. The rougher the surface of the floodplain area is, the lower the velocities are, and the water depth increases. The flow velocities evaluated for variants involving arable areas are about $40 \%$ higher than the velocities calculated for scenarios with the original vegetation. Changes in terrain and channel improvement also have a great impact on the magnitudes of the velocities. There are noticeable differences in the flow velocities between Scenarios B and $\mathrm{D}$, and in the adjusted flat and smooth floodplain the velocities are twice higher than in the natural floodplain, which is forested, while the water is only half so deep. The greatest depths of water are present in Scenario F, where a part of the floodplain has been excluded by dikes.

\section{Evaluating the impact of changes in the floodplain on flood wave transformation}

On the basis of a detailed evaluation of the retention capacity, the dependences of the flooded areas and the flooded volumes on the discharge values were determined for particular scenarios, and transformations of theoretical flood hydrographs with peak discharges $Q_{100}, Q_{20}$ and $Q_{5}$ were calculated using the procedure described above (a multisectional model). Fig. 5 shows clearly that the inundation area in its natural state has a more significant storage capacity than the modified floodplain represented by Scenarios D, E and G. In the case of a natural channel and floodplain, the retention effect already begins to apply at relatively low flow rates, while in the case of a modified channel with improved flow capacity, the inundation does not start until the flow rate exceeds the $Q_{5}$ discharge value. Most water is retained in the floodplain in Scenario B - a natural floodplain, completely forested. By contrast, the least amount of water is retained in Scenario D - a modified channel and floodplain, with arable land use.

Figs. 6 and 7 show the input wave with peak discharge $Q_{100}$ at the inflow boundary of the model, along with the transformed flood hydrograph at the end of the domain for each particular scenario. The 
maximum transformation of a one hundred year flood (reduction of the peak discharge and culmination time lag) occurs in Scenario E - a modified channel and a modified floodplain with full floodplain afforestation. A similar transformation occurs in Scenario $\mathrm{G}$ - a modified smooth floodplain with cross dikes, which are gently overflowed in the case of a one hundred year flood. The least wave flattening and culmination time lag is observed in Scenario $\mathrm{C}-$ a modified, smooth floodplain.
An evaluation of the transformation effect for particular variants of the character of the channel and floodplain and the three modeled flood waves with return periods of 100, 20 and 5 years is summarized in Tab. 2. The table shows the peak time delay and the transformation rate (the percentage ratio of the reduced peak discharge to the peak discharge of the input wave). For each theoretical flood wave, the scenarios are sorted according to their transformation effect. The table shows that

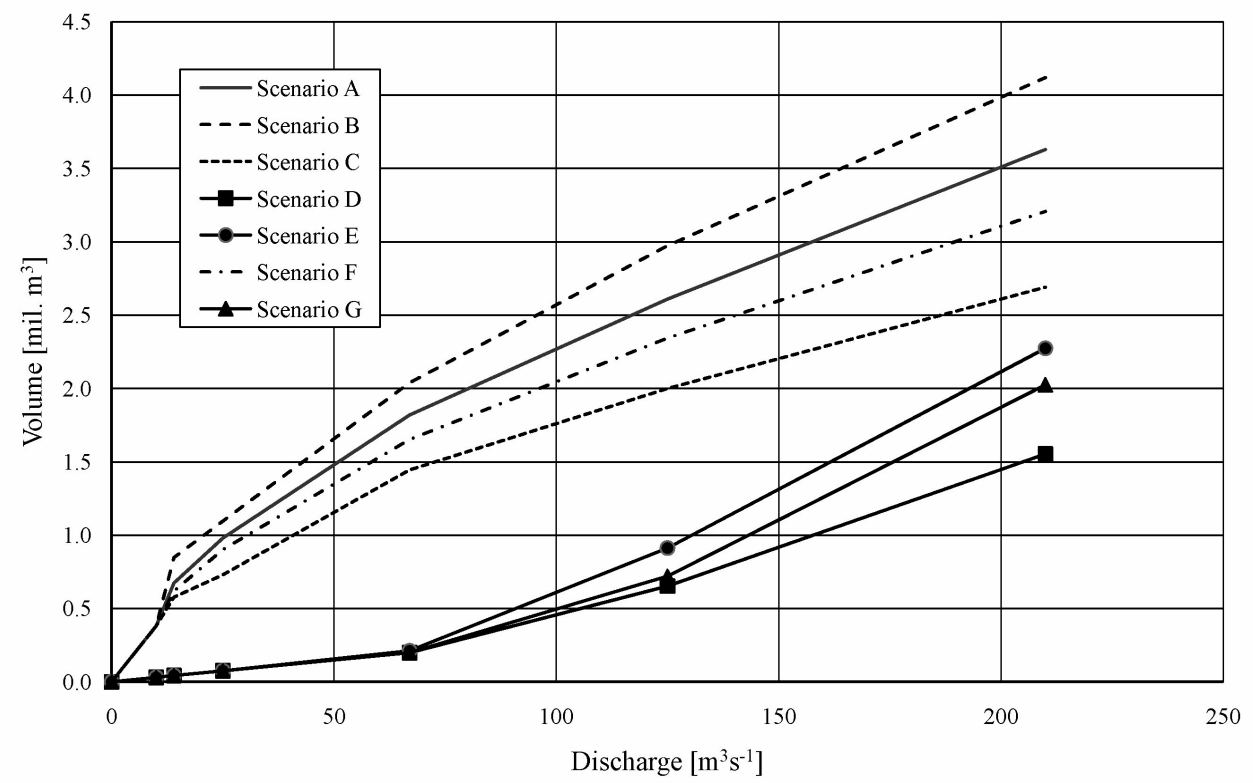

Fig. 5. Discharge - total storage volume relation for particular scenarios.

Obr. 5. Závislost celkových zatopených objemů na průtoku pro jednotlivé scénáře.

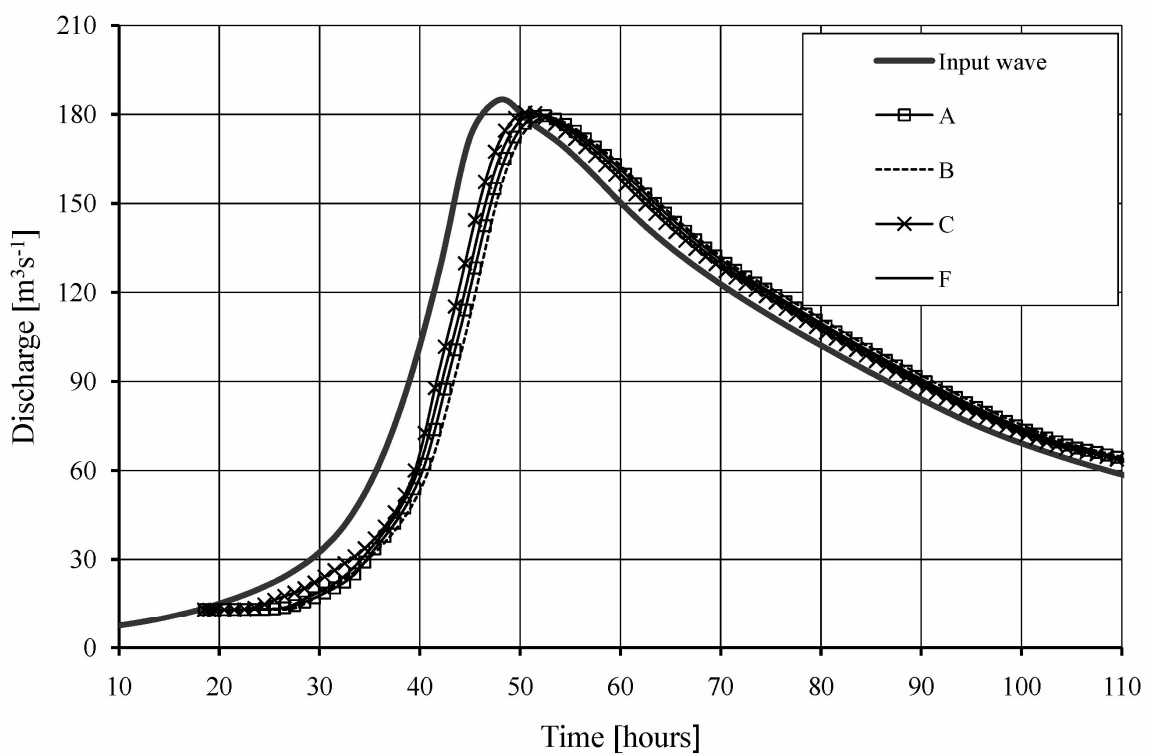

Fig. 6. Transformation of a flood wave with a 100-year return period for the current natural state (Scenarios A, B, C, F). Obr. 6. Transformace povodňové vlny $Q_{100}$ pro přirozený stav toku a nivy (scénáře A, B, C, F). 


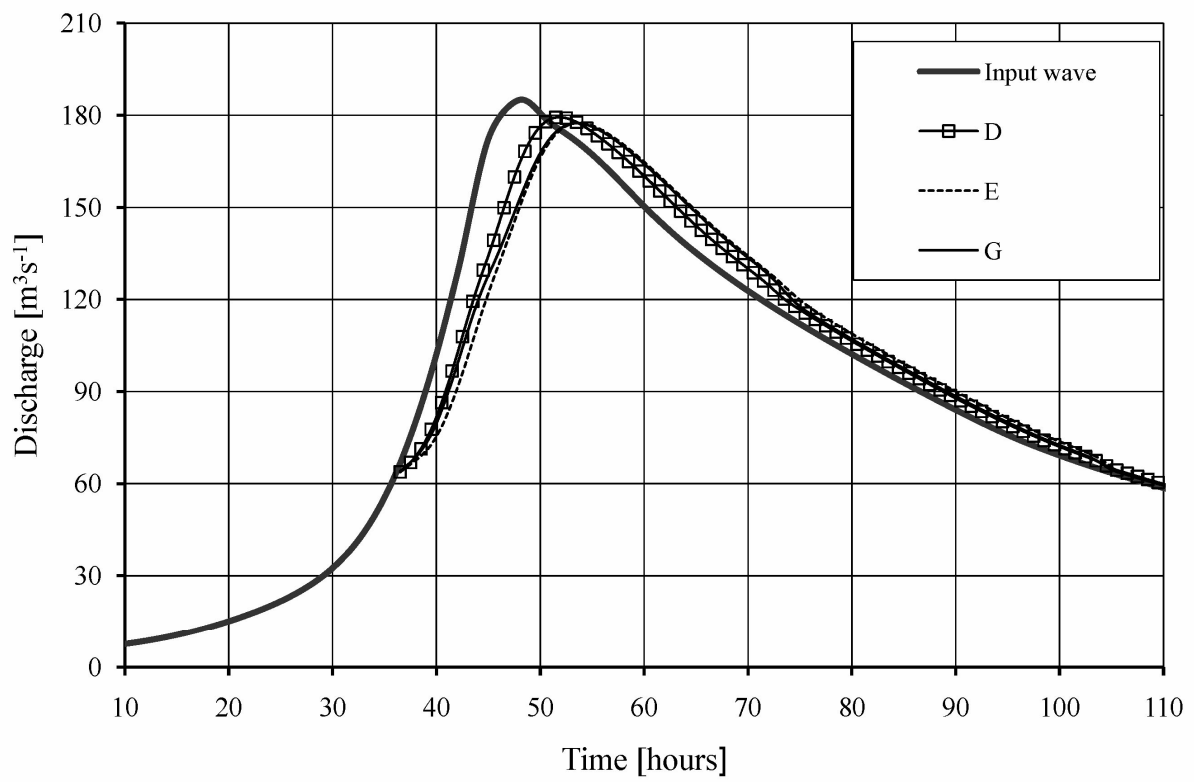

Fig. 7. Transformation of a flood wave with a 100 -year return period for the modified state (Scenarios D, E, G). Obr. 7. Transformace povodňové vlny $Q_{100}$ pro upravený stav toku a nivy (scénáře $\mathrm{D}, \mathrm{E}, \mathrm{G}$ ).

$\mathrm{T}$ a b $1 \mathrm{e}$ 2. Evaluation of flood wave transformation in particular scenarios.

$\mathrm{T}$ a b u $1 \mathrm{k}$ a 2 . Vyhodnocení transformace povodňových vln pro jednotlivé scénáře.

\begin{tabular}{|c|c|c|c|c|c|c|c|c|}
\hline \multirow[b]{2}{*}{ Scenario } & \multicolumn{2}{|c|}{ Input wave $\mathrm{Q}_{5}$} & \multirow[b]{2}{*}{ Scenario } & \multicolumn{2}{|c|}{ Input wave $\mathrm{Q}_{20}$} & \multirow[b]{2}{*}{ Scenario } & \multicolumn{2}{|c|}{ Input wave $\mathrm{Q}_{100}$} \\
\hline & $\begin{array}{c}\text { peak time } \\
\text { delay } \\
\text { [hours] }\end{array}$ & $\begin{array}{c}\text { transformation } \\
\text { rate } \\
{[\%]} \\
\end{array}$ & & $\begin{array}{c}\text { peak time } \\
\text { delay } \\
\text { [hours] }\end{array}$ & $\begin{array}{c}\text { transformation } \\
\text { rate } \\
{[\%]} \\
\end{array}$ & & $\begin{array}{c}\text { peak time } \\
\text { delay } \\
\text { [hours] }\end{array}$ & $\begin{array}{c}\text { transformation } \\
\text { rate } \\
{[\%]}\end{array}$ \\
\hline B & 8.5 & 95.4 & B & 5.5 & 95.8 & $\mathrm{E}$ & 5.5 & 95.9 \\
\hline A & 7.5 & 96.0 & E & 4.5 & 96.5 & $\mathrm{G}$ & 5.5 & 95.9 \\
\hline $\mathrm{F}$ & 7.5 & 96.4 & A & 4.5 & 96.6 & B & 4.5 & 96.7 \\
\hline $\mathrm{C}$ & 6.5 & 96.5 & $\mathrm{~F}$ & 4.5 & 96.8 & A & 4.5 & 97.0 \\
\hline $\mathrm{D}$ & 0.0 & 100.0 & $\mathrm{C}$ & 4.0 & 97.1 & $\mathrm{D}$ & 3.5 & 96.9 \\
\hline E & 0.0 & 100.0 & G & 3.5 & 97.0 & $\mathrm{~F}$ & 3.5 & 97.4 \\
\hline $\mathrm{G}$ & 0.0 & 100.0 & $\mathrm{D}$ & 3.5 & 97.1 & $\mathrm{C}$ & 2.5 & 97.6 \\
\hline
\end{tabular}

inundation with large surface roughness - i.e. a wooded area - is the most suitable scenario for flood wave transformation (with both high and low peak discharge) is an inundation with large surface roughness - i.e. a wooded area. A comparison with other channel improvement scenarios and/or land use changes shows that the floodplain has considerably higher flood mitigation effects in its current natural state.

\section{Conclusion}

The paper describes a method for determining the retention capacity of floodplains with complex geometry using a detailed two-dimensional numerical model. The main advantage of applying twodimensional modeling is the possibility to take into account particular changes in terrain geometry and land use in the area of interest and to study their impact on the retention capacity of the floodplain. The method can be used to assess the retention capacity in inundation areas with different characteristics and land use, and it also enables us to test the effectiveness of various measures that can be used to increase the storage capacity and thus contribute to slowing down the water runoff from the landscape. Changes in geometry are correctly reflected in the detailed two-dimensional numerical results, and yield high-resolution input data for subsequent simulation of the flood transformation. For this purpose, a simple hydrological method based on a non-linear reservoir model was applied in the study presented here. However, due to the simplifications that were adopted, it has to be presumed that the simulation method in its basic form is applicable only for relatively short river 
branches. Especially in cases of steep flood waves, it is preferable to design the model as multisectional (by analogy with a cascade of reservoirs).

The practical applicability of the proposed method was tested in a parametric study of the floodplain retention capacity of a $6 \mathrm{~km}$ long upper branch of the Lužnice River, and the results for the current state and for various hypothetical scenarios of changes in geometry and land use have been evaluated and compared. Some of the scenarios under consideration are only theoretical for the given territory, as the area of interest is located in a nature reserve. However, the results of the study show the impact of various adjustments on the floodplain retention capacity, and may be useful for other inundation areas, where some of the measures may be feasible.

Acknowledgement. This paper was created within the NIVA project on Water Retention in Floodplains and Ways of Increasing Water Retention, and within Research Programme no. MSM6840770002.

\section{REFERENCES}

BATES P.D., ANDERSON M.G., PRICE D.A., HARDY R.J., SMITH C.N., 1996: Analysis and Development of Hydraulic Models for Floodplain Flows. In: Floodplain Processes, John Wiley \& Sons.

BAYERISCHES LANDESAMT FÜR WASSERWIRTSCHAFT, 2005: Einfluss von Massnahmen der Gewasserentwicklung auf den Hochwasserabfluss. Bayerisches Landesamt für Wasserwirtschaft, Materialen Nr. 122, Munchen.

KEMEL M., 2000: Klimatologie, meteorologie, hydrologie. ČVUT v Praze, 2000.

KREIS N., 2003: Re-entering river waters onto floodplains requires hydrological and hydraulics modelling. International Conference Towards Natural Flood Reduction Strategies Warsaw.

KUIPERS J., VREUGDENHIL C.B., 1973: Calculation of Two-Dimensional Horizontal Flow. DHL Report S-163-I, Part I. Delft Hydraulics Laboratory, Delft.

KVĚT J., JENÍK J., PAPÁČKOVÁ-SOUKUPOVÁ L., 2002: Freshwater wetlands and their sustainable future. A case study of Třeboň Basin Biosphere Reserve, Czech Republic. UNESCO and the Parthenon Publishing Group. 495 s. ISBN 1-85070-550-X.

LINK O., DONOSO J., 2008: Development and verification of a numerical model for calculation of flow in open channels using the finite volume method. J. Hydrol. Hydromech., Vol. 56, No. 3 .

PEKÁR J., MIKLÁNEK P., PEKÁROVÁ P., 2001: Riečny model nelineárnej kaskády NLN-Danube pre Dunaj v úseku Ybbs-Nagymaros $\mathrm{v}$ prostredí MS EXCEL. (A nonlinear cascade model for the Danube River between Ybbs and Nagymaros in MS EXCEL.) (In Slovak.) A. Hydrologica Slovaca, 2, No. 2, 130-137.
PITHART D., PRACH K., FRANCÍRKOVÁ T., 2003: Functional river floodplains as the best flood protection: the Luznice River, Czech Republic, experience from August 2002 flooding. International Conference Towards Natural Flood Reduction Strategies, Warsaw.

SARTOR J.F., 2005: Flood Water Retention by Riverine and Terrestrial Forests. In: Proceedings of the 2005 Watershed Management Conference, Williamsburg.

RODI W., 1980: Turbulence Models and their Application in Hydraulics. IAHR Monograph.

SWIATEK D., OKRUZSKO T., CHORMANSKI J., 2003: Natural Floodplain Storage Capacity - Modelling Approach. In: Towards Natural Flood Reduction Strategies, Warsaw.

SZOLGAY J., DANÁČOVÁ M., KOVÁČ P., 2006: Vplyv úprav koryta a výstavby plánovaných poldrov na režim povodní dolnej Moravy. In: Extrémní hydrologické jevy v povodích, sborník př́spěvků, ČVUT v Praze, 2006, s. $153-158$.

SZOLGAY J., DANACOVA M., JURCAK S., SPAL P., 2008: Multilinear flood routing using empirical wave-speed discharge relationships: Case study on the Morava River, J. Hydrol. Hydromech., Vol. 56, No. 4, 2008, p. 213.

USACE, 2001: HEC-RAS River Analysis System. Hydraulic Reference Manual. Hydrologic Engineering Center, Davis, California.

VALENTA P., VALENTOVÁ J., 2003: Detailed Numerical Modeling of Flood Flow in Floodplains with Complex Geometry. Acta Polytechnica, 3, 43, 55-60.

VALENTA P., 2004: Dvourozměrné numerické modelování proudění vody $\mathrm{v}$ otevřených korytech a inundačních územích. [Habilitační práce.] ČVUT, Fakulta stavební, Praha.

VOPÁLKA J., PAŘÍZEK P., 2000: Pomáhá revitalizace vodních toků protipovodňové ochraně? Vodní hospodářství, č. 07.

WATANABE A., FUKUOKA S., 2002: Analysis of the Flood Flow Storage in Compound Meandering Channels by Using Unsteady Two-dimensional Numerical Model. In: River Flow 2002, Proceedings of the International Conference on Fluvial Hydraulics, Lisse, the Netherlands.

WENKA T., VALENTA P., 1991: Entwicklung und Austesten einer tiefengemittelten Version des FAST-2D Computer Programms. Bericht Nr. 671. Institut für Hydromechanik, TU Karlsruhe.

ZEZULÁK J., KŘOVÁK F., SCHLANGEROVÁ H., SOVINA J., KREJČI J., 2006: Posouzení účinků rozlivů velkých řek na průběh hydrogramů. ČZU v Praze.

Received 26 October 2009 Accepted 23. June 2010

\section{KVANTIFIKACE RETENČNÍ SCHOPNOSTI NIVY POMOCÍ 2D NUMERICKÉHO MODELU}

Jana Valentová, Petr Valenta, Lenka Weyskrabová

V souvislosti s častým výskytem povodňových situací $\mathrm{v}$ posledních letech je mnoho pozornosti věnováno problematice ochrany před povodněmi a zejména návrhu opatření, která by mohla zmírnit nepříznivé dopady povodní. Kromě technických opatření, spočívajících ve výstavbě nádrží a suchých poldrů a $\mathrm{v}$ realizaci protipo- 
vodňových opatření $\mathrm{v}$ zastavěných územích, je také možné uskutečňovat opatření $v$ krajině směřující k obnově či zvýšení retenční schopnosti říčních niv. Cílem těchto opatření je zvýšit akumulaci vody v území, snížit kulminační průtok a oddálit dobu kulminace. Míra transformace přitom závisí na tvaru, charakteru a způsobu využívání inundačního území - na jeho retenční schopnosti. Ke kvantifikaci retenční kapacity inundačního území a $\mathrm{k}$ posouzení účinnosti navrhovaných úprav terénu nivy či způsobu jejího využití je zapotřebí použít vhodné numerické metody.

Metoda prezentovaná $\mathrm{v}$ př́spěvku je založena na detailním dvourozměrném numerickém modelování proudění vody za povodně v rríčním korytě a přilehlém inundačním území. Přímé řešení transformace povodňové vlny pomocí nestacionárního dvourozměrného modelu klade mimořádné nároky na výpočetní čas, což často vede $\mathrm{k}$ nutným kompromisům $\mathrm{v}$ použité podrobnosti modelu. Ve složitých reálných geometríích pak může docházet $\mathrm{k}$ numerickým obtížím $\mathrm{v}$ důsledku střídavého zatápění a obnažování terénních hran. $V$ príípadě zde použité metodiky byl proto použit zjednodušený prístup, spočívající $\mathrm{v}$ odděleném řešení proudění vody $\mathrm{v}$ inundaci pro náhradní sérii kvazistacionárních stavů pomocí detailního 2D modelu, ve vyhodnocení závislostí prostorových charakteristik nivy na průtoku a v následném výpočtu transformace povodňové vlny pomocí nelineárního bilančního modelu. Simulace proudění jsou uskutečňovány s využitím numerického modelu FAST2D, jehož matematický základ tvoří soustava Reynoldsových rovnic pro turbulentní proudění. Retenční kapacita je určována na základě podrobného vyhodnocení charakteristik proudění (průběhů hladin, hloubek vody, zatopených ploch a zatopených objemů) pro všechny řešené průtokové stavy.
Účinky retenční kapacity na transformaci povodňové vlny jsou řešeny $\mathrm{v}$ následném výpočtu pomocí nelineárního bilančního modelu založeného na Bratránkově metodě, s využitím vyhodnocené závislosti mezi průtokem a objemem vody rozlité v inundaci podle výsledků 2D simulací.

V př́spěvku je uvedena parametrická studie kvantifikace retenční kapacity nivy, která se zabývá vyhodnocením a porovnáním transformační schopnosti pro nivu Lužnice $v$ jejím horním úseku pro současný přirozený stav a pro rủzné teoretické scénáře změněného charakteru a způsobu využívání nivy. Zájmová oblast (zahrnující meandrující tok Lužnice $\mathrm{v}$ délce $10 \mathrm{~km} \mathrm{~s}$ přilehlou inundací délky $6,5 \mathrm{~km}$ a v šiřce $1,7 \mathrm{~km}$ ) je součástí chráněné krajinné oblasti Třeboňsko a představuje přírodní inundaci s minimem antropogenních vlivů a tudíž s velkou přirozenou retenční kapacitou. Na základě porovnání $\mathrm{s}$ dalšími teoretickými scénáři úprav v nivě a změn způsobu hospodaření studie ukazuje, že současný přirozený stav má pozitivní dopad na snížení účinků povodní.

Studie ukazuje praktickou použitelnost navržené metody, která je vhodná pro př́pady, kdy morfologie inundačního území je variabilní a složitá, jako např́klad př́ípady údolních niv $\mathrm{s}$ meandrujícími toky. Změny $\mathrm{v}$ tvaru terénu jsou dostatečně věrně postiženy ve výsledcích dvourozměrných simulací, které poskytují detailní vstupní data pro řešení transformace povodňových vln. $\mathrm{V}$ prezentované studii byla $\mathrm{k}$ tomuto účelu použita jednoduchá hydrologická metoda podle Bratránka, kterou je v její základní podobě nicméně zapotřebí považovat za přibližnou a aplikovatelnou pouze pro krátké úseky toků. Zejména u strmých povodňových vln je přitom vhodné použitý model koncipovat jako vícesekční (analogie kaskády nádrží). 